\title{
Radicalism in Islamic Education
}

\author{
Ris'an Rusli ${ }^{1}$, Ahlam Binti Ibrahim ${ }^{2}$, Afriyanto ${ }^{3}$, Toharudin ${ }^{4}$ \\ \{risanrusli_uin@ radenfatah.ac.id $^{1}$, ahlamimtiaz@yahoo.com ${ }^{2}$, afriyantobinemri@gmail.com ${ }^{3}$, \\ toharudinrizal@gmail.com $\left.{ }^{4}\right\}$
}

Departement of Aqidah\&Filsafat Islamic, Faculty of Ushuluddin and Islamic Thinking, Universitas Islam NegeriRaden Fatah Palembang Sumatera Selatan, Indonesia ${ }^{1}$

Departement of FiqhContemporari\&Shariah Compliance, Faculty of Islamic Education, Universiti Kebangsaan Malaysia 43600 Bangi, Selangor Darul Ehsan, Malaysia ${ }^{2,3}$

Departement of Islamic Community Development, Faculty of Dakwah and Communication, Universitas Islam NegeriRaden Fatah Palembang, Sumatera Selatan Indonesia 30126

\begin{abstract}
This Radicalism cannot be separated from social life in society or in a group, indirectly these movements will exist when there is a society, this shows that there is a development of diverse human thought patterns. His thoughts that forcefully must be accepted by others, this is what underlies the occurrence of radicalism. A thought that forces others to accept their thoughts is the beginning of radicalism. The higher the ideals of a nation, the more distractions must be passed. This disorder has even existed since a new nation was formed. When a society has a strong character, positive and resilient, then this is a basic capital for the success of a nation. Conversely, if the community has a negative and weak character, then this will result in the weak foundation of the nation to be built. Building the nation's foundation requires values of Islamic teachings. Indonesian Muslims build a new idea, with a new Islamic system and order that is organized in an Islamic way, that idea is the concept of the Indonesian people, a concept that builds an Islamic state without a formal Islamic name. This shows that Islamic education is a major milestone in the establishment of a nation.
\end{abstract}

Keywords-Radicalism, education, Islam.

\section{Introduction}

Islam is a religion which from the beginning of its presence has been in contact with the issue of sovereignty widely. Even the early history of Islam has been filled with stories of the triumph of the government system and the military strategy of the Prophet Muhammad [1]. MusdahMulia, Negara Islam, Depok: Katakita, 2010. In the overall picture of its history, Islam is an endless endeavor to realize the idealized society and that venture involves Muslims in all fields of life, including Islamic education.[2]. Muhammad Azhar, FilsafatPolitikPerbandingan Antara Islam dan Barat, Jakarta: RajawaliPers, 1991. So that Muslim scientists generally concluded that the Prophet MuhammadSAW not only brought Islamic teachings but also brought a new order of knowledge. [3]. Surwandono, PemikiranPolitik Islam Yogyakarta: LPPI. UMY, 2001. Thus Islamic education experiences activities and the process of a very long historical journey and has never stopped until today.Besides being caused by thethingsmentioned above, this is also because Islam has made history for more than 14 
centuries, so it is naive if it is considered that long history is permanent. In the course of its history, Islam has experiences and theories about education which are very rich and broad. This places the discussion about Islamic education as something that continues to develop.

Islam understands humans in a comprehensive approach. Humans consist of physical aspects of the body, which consists of health, success, and neatness. Spiritual aspects related to the development of religious diversity, namely faith and piety to Allah SWT. Emotional aspects related to the development of the affective aspects of religious people or society in general, namely caring, creative, and empathy [4]. SaifuddinZuhri, SejarahKebangkitan Islam danPerkembangannya di Indonesia, Bandung: Al-Maari'f, 1918.Intellectual aspects related to the intelligence of Muslims or society. It is these aspects of character that are developed in Islam and are commendable that can build the character of the nation into superior civilization.

By understanding humans and behavior in the perspective of Islam, human beings consist of physical, spiritual, and nafsani elements that make humans as perfect beings on earth. Humans have the freedom to choose good or bad behavior, right or wrong, therefore human beings are provided by Allah SWT with reason and heart. [5]. SaifuddinZuhri, SejarahKebangkitan Islam danPerkembangannya di Indonesia. The elements that exist in humans need healthy growth and development in order to carry out human functions as khalifatul fil ardih which can carry out humanitarian tasks, the process of human growth and development will be achieved optimally through education that can develop all the elements and potential that exists in him. Likewise, Kuntowijoyo's idea which states that humans in Islam are depicted as independent beings, and because of the nature of their independence, humans occupy a very respectable place (as the representative of Allah SWT on earth). In many verses of the Qur'an it is called for man to find his essence, think of his position in the structure of reality, so as to be able to position himself in accordance with his human existence [6] Kuntowijoyo, Islam SebagaiIlmu, Metodologi, danEtika, Jakarta: PenerbitTerajut, 2004.

Intellectuals are often also referred to as the results of one's thoughts, which include the benefit of mankind in With the Islamic education paradigm that teaches liberation, not restraint like other religions, human self-actualization can be realized perfectly in theservice of their creator. This is clearly a true liberation, so it can be concluded that Islam has the power to be the basis for the conception of behavior and systems of ideas needed in overall life, this is what is called Islamic education. By re-actualizing Islamic values in education that has positive synergy, the superior character of the nation can be formed effectively.Lately, there has been an increase in the radicalization of education radicalization in the name of Islam, which in its understanding wants to conduct jihad to form a khilafa state. This raises a very big question in this nation, is this part of the maturity of education or part of the decline in education?. This is the starting point of thought that seeks to solve this problem.

\section{Discusion}

\subsection{Islamic Education}

This There was an interesting dialogue between a Brazilian theologian named Leonardo Boff and the Dalai Lama in a roundtable discussion[7] Idzam Pautanu, Tabah Rosyadi, NilaiNilai Keislaman Untuk Membangun Karakter Bangsa. Jakarta: UIN Syarif Hidayatullah, 2010."what makes a person good? If someone becomes more patient, intuitive, caring, has a sense of humanity, responsibility and ethics, then religion has worked for you. The universe is 
a reflection of what humans think and what humans do. If man does good, then he will receive good, if man commits evil, then he will accept evil. "This dialogue indicates how religion can be very functional and work well, when religion can be reflected in a person's daily behavior to become a good person. Religion is not a separate value from real life, but integrated in human behavior means religion is an educational pattern that forms a society.

Lately there has been a very worrisome social phenomenon, marked by various degradations of moral ethical life that occur in a variety of spheres. Doni Kusuma, [8]. Doni Kusuma, Kompas Cyber Media, 2009.Mentioned several phenomena namely the nation's moral bankruptcy, rampant violence, incoherence of politicians or political rhetoric, and daily behavior. In line with DoniKusuma who declared the nation's moral bankruptcy, Mohammad Amien Rais, [9]. Mohammad Amien Rais, Agenda- Mendesak Bangsa Selamatkan Indonesia, Yokyakarta: PPSK Press, 2008.Argued that recently in Indonesia there had been a setback of social phenomena, and the social moral approach that emerged lately was quite alarming. The phenomenon of violence in solving problems becomes common. Policy coercion occurs at almost every level of the institution. Manipulation of information is commonplace. Emphasizing and coercing the will of one group against anothergroup is considered normal. The law is so thorough about mistakes, but blind to justice.

It seems that the character of the Indonesian people who are polite in their behavior, consensus agreement in solving problems, a region rich in plurality, tolerance and mutual cooperation, has transformed into a hegemony ofnew groups that defeat each other [10] AanHasanah, PendidikanBerbasisKarakter. Jakarta: Media Indonesia, 2009. Even in the last ten years violence and riots have risen sharply. Cases of violence occur in various dimensions, including political, economic, and even religious backgrounds. Cases of violence that have emerged prominently in recent years include cases of violence against children and women, cases of social violence, as well as cases of religious violence, intimidation of educators, and the lack of Islamic education facilities that impact on mutual disbelief and blame in groups or Islamic education organization.

According to IdzamFautanu [11] IdzamFautanu, NilaiNilaiKeislamandanKeindonesiaanUntukMembentukKarakterBangsa, Seminar Loncing: UIN Readen Fatah, 2015."in addressing the recent events, an epistemological question has arisen, how can Islamic values manifest in the character of the Indonesian nation?" Indonesian people have superior character which will build superior nation. Central of the world was built by nations that have advantages not only in the fields of science and technology but the most important is a nation whose inhabitants, people have noble, honest, responsible character, become good, strong, positive independent citizens, hard-working and Islamic-educated. These character forms will make a nation have the distinction and respect for the association of the nations of the world.

Mohammad AmienRais explained that when the majority of the community's character is strong, positive, resilient, a high nation can be built well and successfully, conversely if the majority of the community's character has a negative and weak character resulting in a weakened nation being built, because the dignity of a nation is built on the foundation who is very weak[12] Mohammad AmienRais, Agenda- MendesakBangsaSelamatkan Indonesia Yokyakarta: PPSK Press, 2008.The character of education is the basic capital to build a highranking nation, a society that has an honest, independent, cooperative, regulatory, reliable, tough, and has a high work ethic will produce an orderly and good social life system. Social disorder produces various forms of crime, violence, terrorism, and others. Responding to the character of the nation Mohammad AmienRais [13] Mohammad AmienRais., Islam dan Tata 
Negara: ajaran, sejarahdanpemikiran Indonesia. Jakarta: UI Press, 1991.Divides two moral aspects, namely.

Concept of the Indonesian nation conceptually using moral pillar, that are Individual and communal characters are built through two interrelated aspects namely autonomy and heteronomy. Autonomy is an effort in the education process that is implemented through teaching, habituation, modeling, motivation, and enforcement.Meanwhile, the heteronomy aspect is an effort carried out by the environment (outside of education), namely the existence of socio-economic justice, law enforcement without consideration, leadership model, and regularity of social norms In shaping the nation's character, a strong synergy is needed between aspects of autonomy and aspects of heteronomy. If one of them is fragile or even contradictory, then the nation's character will not be effectively formed. From the aspects of heteronomy offered by Mohammad AmienRais, the above can be described as follows: Aspects of social economic justice, with the existence of social and economic justice, it will free people from prolonged conflict due to inequality and injustice in enjoying the results development. There are a small number of people who can enjoy most of the prosperity in the middle of a large number of people who can only enjoy a small portion of prosperity. This is where the potential for conflict is very latent, which if it cannot be resolved will damage the life of the nation and state.

The aspect of law enforcement, the law is directive direct the behavior of people, which one that must and should not be done in the context of social interests. In law there are consequences that must be borne by each person, so that with the existence of law enforcement, people will know the boundaries of their respective rights and obligations relating to the interests of themselves and others.

The exemplary aspect of national leadership; will be an important node in the formation of a nation's character. If the leader obeys the rules, consistent and understated, then the leader will become a role model for those he leads. Good and noble character dreamer will be a real example of the desired character shape. Meanwhile, a nation that has a strong character will become a nation that can lead the world civilization.

The aspect of regularity of social norms, social order can guarantee all interests, both individual and group. These interests can be fulfilled naturally without conflict with other parties. Therefore, social interaction for a child is very important in shaping good social character and being able to produce good prospective citizens. Without these aspects, the construction of the nation's character will not be effectively realized, if there is widening socio-economic inequality, weak law enforcement, lack of leader example and chaos of increasingly social norms

The values of Islamic education are universal and cosmopolitan noble values of the Indonesian people. These values must of course be based on religion or culture resulting from a long dialogue with religion (Islam). These values have a strategic and central role in building the unity of the people. This unity fosters stability as a nation. Therefore the growth of stability runs parallel to the growth of the values of Islamic education itself. This stability has implications for self-freedom from fear of plurality or anxiety to the current of globalism or foreign influence. So that the stability of the values of Islamic education becomes the base of a phase of further growth which is more important, namely the phase of openness or in contemporary terms is inclusiveness.

Inclusiveness [14] NurcholishMadjid., Islam KemoderenandanKeindonesiaan. Bandung: Mizan, 1999. in religious life is one of the most important aspects of citizens, the people of a plural nation. For this reason, NurcholishMadjid (CekNur) said that "Indonesia is one of the most plural nations in the world", or in other words that the population of Indonesia is the 
most diverse religion and culture on earth. Mohammad AmienRais [14]. Mohammad AmienRais, Indonesia's Muslim Parties and Their Political Concept, 2000.thus concluded that a conclusion can be made that the "Islamic education" of the Indonesian people is very religious, despite the reality in that diversity is predominantly Muslim. Islam entered Indonesia by peaceful means [15[NurcholishMadjid, MencariAkar-Akar Islam BagiPluralisme Modern, Pengalaman Indonesia, Dalam Mark R. Woodward,JalanBaru Islam, MemetakanParadigmaMutakhir Islam Indonesia. Bandung: Mizan, 1998. For this reason, the most valuable Indonesian capital is unity, the territorial integrity of the country, the language of unity, constitution and state philosophy. The government system which covers the whole of the motherland and pragmatic economic development

In line with the words of Mohammad AmienRais, in addition to Indonesian capital, the other most expensive capital is the capital of the experience of the Indonesian people in living a pluralistic community life. This capital, namely Indonesian-ness, shows a general tendency towards the realization of national convergence, a form of mutual understanding rooted in the spirit of giving and receiving. This attitude leads to the stability of each group, group, and religion, and the loss of worry between them. On the basis of the pluralism or internal pluralism of Indonesian society and the tendency towards solid national convergence, the development of Islamic education in Indonesia requires proper understanding and strategy [16] NurcholishMadjid, MasyarakatReligius. Jakarta: Paramadina, 2000.

From this then gave rise to thoughts about Indonesian insights. Mohammad AmienRais asserted that the Indonesian insight is understanding and knowledge of the socio-cultural environment of Indonesian society as a whole [17] Mohammad AmienRais, Indonesia's Muslim Parties and Their Political Concepts, Thesis untuk Master of Arts, Graduate School. Washinton DC: George Town University, 1998.

Therefore, it must be taken into account that Indonesia is a nation state that has a high physical diversity, namely the archipelago, the diversity of ethnicities, languages, customs, and religions. Seeing this reality, every step in the implementation of Islamic teachings in Indonesia must take into account the socio-cultural conditions to progress [18] Mohammad AmienRais. Indonesia's Muslim Parties and Their Political Concepts, Thesis untuk Master of Arts, Graduate School. Washinton DC: George Town University, 1998.

The Indonesian people are heading towards a nation state, this means towards a democratic, egalitarian and fair. Indonesia is a country with diverse populations and diverse cultures. These diverse cultures can support the realization of a nation state that is in line with the ideals of the country. In this case the most important thing to do is, the diverse culture must be manifested in the direction of Indonesianism with Islamic education. In the course of national history, the process of Indonesian-ness is not limited to one place and at one time. As often expressed by the nation's leaders that Indonesian-ness has deep roots in the history of the archipelago

\subsection{Radicalization}

Radicalism can be interpreted as an understanding or flow that wants drastic social or political change or renewal by using violent methods [19] Ashutosh Varshney, Konflik Etnis dan Peran Masyarakat Sipil Pengalaman India. : Jakarta: Balai Penelitian dan Pengembangan, 2009. The meaning of radicalism in a religious perspective can be interpreted as a religious understanding that refers to a very basic religious foundation with a very high religious fanaticism, so it is not uncommon for adherents of the sect or sect to use violence to actualize the religious beliefs held and believed. 
The process that occurs in radicalism is radicalization, which is defined as a personal process in which individuals adopt political, social or religious ideals and aspirations to the extreme, which in achieving their goals justifies the use of violence indiscriminately, thus preparing and motivating someone to achieve violent behavior. The formation of radicalism is achieved through a process of radicalization in which there are (three) aspects that have an important role during the process, namely: The process of individualization of radicalization is seen as one of the processes of seeking identity for individuals (young people in general). [20] Ashutosh Varshney, Konflik Etnis dan Peran Masyarakat Sipil Pengalaman India, 2009.

For young people, the search for identity is part of the process of defining one's relationship with the world. Interpersonal Dynamics Radicalization requires interpersonal interaction with other actors to stimulate and influence the process of understanding or thinking of individuals who are targeted by radicalism.

Symptoms of religious violence are more precisely seen as socio-political symptoms rather than religious phenomena; in this case radicalism views the historical fact that groups who have the same religious conviction as they are not benefited by global civilization thus causing resistance to the forces that dominate. Radicalists try to touch religious sentiments and emotions, and gather strength to achieve their political goals through religious language and slogans.

Religious solidarity for friends who are oppressed by certain powers. In this context what is meant by religious emotion is religion as an interpretive understanding of reality. Cultural factors People are known to always try to break away from the snare of certain cultural webs that are deemed incompatible with their culture. An example of cultural factors in radicalism is the cultural influence of Western secularism education on Islamic culture, which is considered by Islamic radical groups to marginalize their ideology and culture. Ideological factors. Inability to position themselves as competitors in culture and education, makes radical groups take the path of violence to show the existence or hegemony of their culture

Whilethe second radicalization process results from the dynamics of social interaction in micro conditions that are influenced by the media, peers, leaders, family members, or the surrounding environment, so that they accept a belief system or understanding that something can and must be done to deal with things that pose a threat to the flow of trust or understanding that it believes. The emergence of religious radicalism occurs as a result of the following: Claims of truth Adherents of religions believe that their sacred books do teach monolithic truth (singular), where there are often interpretations that assume that other religions are untrue.

Radicalism in the sense of language means understanding or flow that wants social or political change or renewal in a violent or drastic manner. However, in another sense, the essence of radicalism is the concept of the attitude of the soul in carrying change. Meanwhile radicalism in another sense is the core of the change tends to use violence. What is meant by radicalism is a movement that is conservative and often uses violence in teaching their beliefs. While Islamic education is a religion of peace that teaches an attitude of peace and the search for peace. Islam has never justified the practice of using violence in spreading religion, religious understanding and political understanding.

Dawinsha argues that the definition of radicalism equates it with terrorism. But he uses radicalism by distinguishing between the two. Radicalism is a policy and terrorism is part of a radical policy. Dawinsha's definition is more evident that radicalism contains an attitude of the soul that leads to actions aimed at weakening and changing the order of establishment and replacing it with new ideas. The latter meaning, radicalism is as negative understanding and can even be dangerous as extreme left or right. 
The emergence of social issues regarding Islamic education radicalism is a new challenge for Muslims to answer it. The issue of radicalism in Islamic education has actually been sticking out for a long time on the surface of international discourse. Radicalism of Islamic education as a historical-sociological phenomenon is a problem that is widely discussed in the discourse of intellectualism and global civilization due to the power of the media which has great potential in creating the perception of the world community. Many labels are given by Western Europeans and the United States to refer to the radical Islamic education movement, from the term hardliners, extremists, militants, right Islam, fundamentalism to terrorism. Even in Western countries after the collapse of the ideology of communism (post-cold war), viewing Islamic education as a movement of frightening civilization. There is no political upheaval that is more feared than the rise of the Islamic education movement which it labels as Islamic radicalism. Western accusations and propaganda against Islam as a religion that supports the movement of radicalism has become an international rhetoric.

The label of radicalism for the Islamic education movement that opposes the West and its allies is deliberately made an educational commodity. Palestinian resistance movement in combating ignorance and occupation, Iran's Islamic Revolution, Al-Jazair's FIS Party, anti-US behavior displayed by Mu'ammarGhadafi or Saddam Hussein, Islamic movement in Southern Mindanao, Sudanese anti-US Muslim community, spread of the anti-US Muslim community, Indonesian Muslim solidarity with the oppressed brothers and so on, is a phenomenon used by Western media in campaigning the label of Islamic education radicalism. But it cannot be denied that in the course of its history there were certain Islamic groups that used violence to achieve the goals of Islamic education or maintain a rigid religious understanding which in the language of global civilization is often called the radicalism of Islamic education.

According to the Chief Executive of NahdatulUlama (PBNU), Ahmad Bagja, radicalism arises because of injustices that occur in the community. This condition could have been caused by countries or other groups that differed in understanding, as well as beliefs. Those who feel they have been treated unfairly then put up a fight. Radicalism is not uncommon for some Muslims to respond to a situation. For them, radicalism is a choice to solve problems. But some other groups, they will against radicalism in any form. Because they believe that radicalism does not solve anything. It will even give birth to other problems that have a prolonged impact. Furthermore, radicalism will instead make the image of Islamic education a religion that is intolerant and full of violence

Muslim scholar Nazaruddin Umar said that radicalism did not exist in Islamic history, because so far Islam does not use radicalism to interact with other worlds. "In its history, the Prophet always taught his people to be gentle," he stressed. This means, Nazaruddin explained that the spread of Islamic teachings or Islamic education carried out by the Prophet Muhammad was carried out in a polite and gentle manner. The Prophet taught to pay respect to others even to different beliefs. Nazaruddin added that the teachings of Islam that entered Indonesia were also brought in a very peaceful way. The same spread of Islam took place in other countries.

The radicalism movement is actually not a movement that just appeared but has a background which is at the same time a driving factor for the emergence of the radicalism movement. Among the factors are: First, social-educational factors. Symptoms of "religious" violence are more properly seen as social-educational symptoms rather than religious symptoms. The movement which was mistakenly referred to by the West as the radicalism of Islamic education is more precisely seen from the root of the problem from the point of the social-educational context within the framework of human historicity in society. 
As AzyumardiAzra revealed that the deteriorating position of Muslim countries in the north-south conflict became the main pillar of the emergence of radicalism. Historically we can see that conflicts caused by radicals with a set of violence tools in opposing and colliding with other groups are actually more rooted in socio-educational problems. In this case, radicalism views the historical fact that Muslims are not benefited by global civilization, thus causing resistance to dominating forces. By bringing language and religious symbols and slogans, radicalists try to touch religious emotions and gather strength to achieve the "noble" goals of their politics. Of course this cannot be called manipulating religion because part of their behavior is rooted in religious interpretations in looking at historical phenomena. Because he saw a lot of Islam and Discourse of social deviation and inequality that harms the Muslim community, there was a radicalism movement that was supported by religious sentiments and emotions.

Second, religious emotional factors. It must be admitted that one of the causes of radicalism is a factor of religious sentiment, including religious solidarity for friends who are oppressed by certain forces. But this is more accurately said as a factor of his religious emotions, and not religion (absolute holy revelation) even though the radicalism movement always raises religious flags and symbols such as the pretext of defending religion, jihad and syahiddeath. In this context what is meant by religious emotion is religion as an interpretive understanding of reality. So it is relative and subjective.

Third, this cultural factor also has a large enough share behind the emergence of radicalism. This is reasonable because it is culturally, as revealed by Musa Asy'ari that in society there is always an attempt to break free from the web of certain cultural nets that are considered inappropriate. What is meant by cultural factors here is as anti-thesis against the culture of secularism. Western culture is a source of secularism that is considered an enemy that must be removed from earth. While historical facts show the dominance of the West in various aspects over Muslim countries and culture. Western education is now the dominant and universal expression of humanity. The West has deliberately carried out the process of marginalizing all aspects of Muslim life so that Muslims become backward and oppressed. The West, with its secularism, has been seen as a nation that pollutes Eastern and Islamic cultures, and is also considered the greatest danger of the continuity of Islamic morality.

Fourth, ideological factors are anti-westernizing. Westernize is a thought that endangers Muslims in applying Islamic sharia. So that Western symbols must be destroyed in order to uphold Islamic Sharia. Although the motivation and anti-Western movement cannot be blamed on the grounds of religious belief, the path of violence taken by radicalism actually shows their inability to position themselves as competitors in Islamic culture and education

Fifth, government policy factors. The inability of governments in Islamic countries to act to improve the situation over the growing frustration and anger of some Muslims is due to the ideological, military and economic dominance of large countries. In this case the government elites in Muslim countries have not been or are less able to find the roots that are the cause of the emergence of acts of violence (radicalism) so that they cannot overcome the social problems faced by the people. In addition, the factor of the mass media (press) of the West which always corners Muslims is also a factor in the emergence of violent reaction by Muslims. Propaganda through the press does have tremendous power and is very difficult to ward off so that some people do "extreme" action as a reaction to what is inflicted on the Muslim community. 


\subsection{Is Radicalism Part of Islamic Education?}

Radicalism is not in accordance with the teachings of Islam so it is not appropriate to be addressed in the Islamic religion because in fact there is no such thing as radicalism. In the Qur'an and the Hadith commands its people to respect and love one another and be gentle to others even though they are followers of other religions. Violence in the form of war was not started by Muslims themselves. Likewise in the history of the struggle of the Prophet Muhammad SAW, the battle of Badr, uhud, and others was not the Muslims who invited the infidels, but instead. Muslims are actually instructed to keep doing well to anyone, including non-Muslims who can live in harmony. Regarding this matter, Allah also said in Surah Al Mumtahanah verses 8 and 9 "Allah does not forbid you to do well and just towards those who do not fight you in religion and do not drive you out of your villages because Allah is pleased with those who fair. Allah only forbids you to be friends with those who fight you in religion and expel you from your villages and help each other to expel you, whoever befriends them they are wrongdoers".

Islam always teaches Muslims to prioritize educational stability and security. Because Islam as a religion of mercy does not want the shedding of the blood of Muslim people and the blood of infidels due to political defamation and security disturbances. For this, Allah teaches several political and security principles to achieve stability in both. Islam really hates tyrannical action whatever its form, because Islam always teaches and commands its people to uphold peace, friendship, and compassion (rahmatanlil 'alamin). Even the Qur'an states that those who commit acts of tyranny are among those who lose out in their lives.

Radical movements not only as a movement that will destroy the life order of religious people but will also damage the education of a country. The deep fear in his society shows the success of radicalism which is prevalent in the era of modern civilization. Many things werelearned from movements carried out by radicalism practitioners, which recently happened. The more advanced a civilization, the stronger the disruption will maturing. As Bastari Ahmad said, the higher the coconut tree, the stronger the wind will hit, leaving a strong root will hold to support the leaves and the coconut tree will survive.

Taking from what has been said above that the higher a civilization that a nation wants to reach, the more that must be passed, the disturbances that come. Even from the beginning of the formation of a seed in a country, there is already a disturbance that will come, such asradicalism. So every maturity of an education will be accompanied by radical movements which are part of the education itself. The Early Period of Muslims was marked by various forms of radicalism both intellectual nature that occurred during the Friends, incited among Muslims and even the occurrence of war. The same condition is also occure to non-Muslims, who suffered the Cold War where a lot of human casualties, as well as many more. All of that shows that radicalism is part of education itself which must be directly served in defending the truth. Without radicalism, a nation's education will not experience maturity and its readiness to face the challenges that will come.

\section{Conclusion}

A superior nation in the world is built by nations that have advantages not only in the fields of science and technology but the most important is a nation whose inhabitants, people, or humanity have noble, honest, responsible character, become good citizens, strong, 
independent positive, and hard-working. Through education that is substantively the values of Islamic teachings; the Indonesian people develop new sciences. On top of these new sciences, a new social system is built. With this new social system, Muslims organize new communities. With this new Islamic society that is organized, Muslims build an Islamic civilization without the formal name of Islam. With the building of Islamic centuries that Muslims can compete and surpass other world civilizations, intelligently and with dignity.

\section{Introduction}

[1.] Azhar, Muhammad. (1997). FilsafatPolitikPerbandingan Antara Islam dan Barat. Jakarta: Rajawali Pers.

[2.] AmienRais, Mohammad. (2008). Agenda- MendesakBangsaSelamatkan Indonesia !. Yokyakarta: PPSK Press.

[3.] .......... (1999). Indonesia's Muslim Parties and Their Political Concepts, Thesis untuk Master of Arts, Graduate School. Washinton DC: George Town University.

[4.] ….......(1991) Islam dan Tata Negara: ajaran, sejarahdanpemikiran Indonesia. Jakarta: UI Press.

[5.] Fautanu, Idzam. (2015). DalamMakalah. NilaiNilaiKeislamandanKeindonesiaanUntukMembentukKarakterBangsa. Seminar Loncing UIN Readen Fatah.

[6.] Hasanah, Aan. (2009).PendidikanBerbasisKarakter. Jakarta: Media Indonesia.

[7.] Kuntowijoyo. (2004). Islam Sebagaillmu, Metodologi, danEtika. Jakarta: PenerbitTerajut.

[8.] Kusuma, Doni.Kompas Cyber Media, 2009.

[9.] Madjid, Nurcholish. (1999). Islam KemoderenandanKeindonesiaan. Bandung: Mizan.

[10.] ........... (1998). MencariAkar-Akar Islam BagiPluralisme Modern, Pengalaman Indonesia, Dalam Mark R. Woodward,JalanBaru Islam, MemetakanParadigmaMutakhir Islam Indonesia. Bandung: Mizan.

[11.] …....... (2000). MasyarakatReligius. Jakarta: Paramadina.

[12.] Mulia, Musdah. (2010). Negara Islam. Depok: Katakita.

[13.] Rosyadi, Tabah. (2015). Nilai-NilaiKeindonesiaaDalamMembentukKarakterPeradabanBangsa, Jakarta: UIN SyarifHidayatullah.

[14.] Rusli, Ris'an. (2014). PembaharuanPemikiran Modern dalam Islam. Jakarta. RajaGrafindoPersada.

[15.] …........ (2015). Teologi Islam: TelaahSejarahdanPemikiranTokoh-Tokohnya. Jakarta. Kencana.

[16.] Surwandono. (2001). PemikiranPolitik Islam. Yogyakarta: LPPI. UMY.

[17.] Syafii Anwar, M. (2012). PemikirandanAksi Islam Indonesia. Jakarta: Paramadina.

[18.] Pautanu,Idzam.TabahRosyadi. (2015). Nilai-NilaiKeislamanUntukMembangunKarakterBangsa. Jakarta: UIN SyarifHidayatullah.

[19.] Varshney, Ashutosh. (2009). Konflik Etnis dan Peran Masyarakat Sipil Pengalaman India. Balai Penelitian dan Pengembangan: Jakarta.

[20.] Zuhri, Saifuddin. (1981). SejarahKebangkitan Islam danPerkembangannya di Indonesia. Bandung: Al-Maari'f. 